\title{
Tid til pasienten
}

\author{
Det er ingen krise i det norske helsevesenet. De aller fleste får god behandling, og et overveldende flertall \\ som har vært i kontakt med helsetjenesten, er fornøyd. Nordmenn lever lenger, overlever mer og kan \\ behandles for stadig flere tilstander. Samtidig står vi overfor store utfordringer i helsepolitikken, som \\ krever en ny politikk.
}

For det første: Norge har store sosiale helseforskjeller. For eksempel får en universitetsutdannet bestefar i snitt sju år mer med sitt barnebarn enn bestefaren som droppet ut etter grunnskolen. For det andre: Selv om de fleste pasientene får god hjelp når de trenger det, gjelder det ikke alle. Utfordringen vil bli større i fremtiden, når enda flere vil trenge stadig mer helsehjelp. For det tredje: Helsepersonell har i flere år ropt et klart og tydelig varsku om kapasiteten og tidsbruken i helsevesenet. For mye tid brukes på unødvendig rapportering, og det er for få hender til å ta seg av pasientene.

Disse tre utfordringene henger sammen. Når ikke alle som trenger hjelp, får den raskt nok, går det særlig utover dem som sitter nederst ved bordet. Når helsepersonell må bruke mer tid på å rapportere kvalitet enn å skape kvalitet, er det vanskelig å gi alle pasienter god helsehjelp.

\section{Tillit og frihet}

Vi må gjøre det vi kan for at flest mulig skal få hjelp raskt, og for at ventetidene for alle typer operasjoner skal gå ned. Men når behovet for helsetjenester går mot uendelig, og ressursene - ikke minst i form av antall ansatte - er begrenset, er det vanskelig ikke å se for seg en form for køordning. Viktigere enn et helsevesen helt uten kø, er det å sikre umiddelbar behandling av høy kvalitet for dem som trenger det aller mest.

Skal vi lykkes med det, må helsevesenet organiseres annerledes enn i dag, slik at helsefaglig personell i større grad făr brukt sin kompetanse til beste for pasienten og samfunnet. Sosialistisk Venstrepartis kur har to hovedingredienser. For det første: frigjøre tid som leger og sykepleiere kan bruke på pasientene. For det andre: fjerne markedsmekanismer i helsevesenet. Det betyr færre private aktører, sterkere offentlige sykehus og slutt på finansieringsord- ninger som gjør noen pasienter mer lønnsomme enn andre.

Sykehusleger bruker under halvparten av tiden sin på pasientrettet arbeid, og helsepersonell over hele landet forteller om overveldende rapporteringskrav. Hvert enkelt krav kan fremstå som fornuftig, men summen blir uhåndterlig og bidrar ikke til bedre pasientbehandling totalt sett. Sosialistisk Venstreparti vil erstatte rapportering med tillit og frihet. Politikerne må styre mer i det store, på bekostning av byråkratene, og mindre i det små - til fordel for legene, sykepleierne, helsefagarbei-

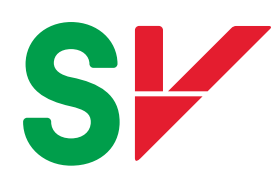

derne og pasientene. Vi vil at Stortinget skal vedta en fireårig nasjonal helseplan som legger de overordnede føringene for sykehuspolitikken. Samtidig vil vi fjerne store deler av rapporteringskravene som er pålagt de ansatte, og gjøre rapporteringen som står igjen, mer effektiv gjennom et IKT-løft i helsevesenet. Sykehusene, avdelingene, klinikkene og den enkelte lege må få større frihet til å organisere sin egen hverdag.

For å gi helsepersonell tid til pasientene må det også flere fagfolk til. Faste ansettelser, heltidsstillinger og økt grunnbemanning er nøkkelen. Flere leger, sykepleiere og helsefagarbeidere betyr mer pasientbehandling, mer tid til hver pasient og kortere helsekøer.
Bort med innsatsstyrt finansiering Byråkratiseringen av helsevesenet henger sammen med markedsmekanismene sykehusene styres etter. Dagens organisering er bygd på en foretaksmodell der regionale helseforetak styrer driften, store deler av finansieringen er innsatsstyrt, og sykehusene styres etter kortsiktige økonomiske mål. Ifølge Legeforeningen mener tre av fire leger at sykehusets økonomiske prioriteringer hindrer dem i å utføre arbeidet på en best mulig måte.

Jeg mener at vi må bort fra ordningen med innsatsstyrt finansiering, fordi faglige vurderinger ikke skal trues av systemhensyn eller økonomiske incentiver. Innsatsstyrt finansiering må erstattes med rammefinansiering, slik at sykehusene kan gjøre vurderinger av ressursfordeling etter behov. Foretaksmodellen må erstattes av en mer demokratisk modell, der det som ikke styres av politikere, må styres av fagfolk ikke økonomer.

Jeg har tillit til legene og sykepleierne. La oss organisere helsevesenet slik at de ansatte får større frihet til å organisere sin egen hverdag etter faglige vurderinger. Det vil gi mer tid til pasientene, mer rettferdige prioriteringer, færre feil og færre reinnleggelser. Hvordan vi kommer dit, bør være den viktigste helsepolitiske saken i valgkampen.

\section{Audun Lysbakken \\ audun.lysbakken@stortinget.no}

Audun Lysbakken (f. 1977) er stortingspolitiker, leder av Sosialistisk venstreparti og medlem av Helse- og omsorgskomiteen på Stortinget.

Mottatt 26.6.2013 og godkjent 27.6.2013. Medisinsk redaktør Hanne Støre Valeur. 